\title{
Oligodendrocytes Originate in a Restricted Zone of the Embryonic Ventral Neural Tube Defined by DM-20 mRNA Expression
}

\author{
S. Timsit,, S. Martinez, ${ }^{2}$ B. Allinquant, ${ }^{3}$ F. Peyron, ${ }^{1}$ L. Puelles, ${ }^{2}$ and B. Zalc ${ }^{1}$ \\ 'Laboratoire de Neurobiologie Cellulaire, Moléculaire et Clinique, INSERM U-134, Hôpital de la Salpêtrière, \\ Université Pierre et Marie Curie, 75651, Paris Cedex 13, France, ${ }^{2}$ Facultad de Medicina, Departamento de Ciencias

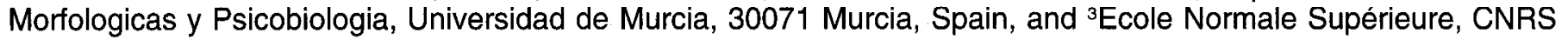 \\ URA 1414, 75230, Paris Cedex 05, France
}

Products of the PLP gene, proteolipid protein and its isoform DM-20, are the most abundant proteins in CNS myelin, and are markers of the oligodendrocyte, the myelin-forming cell in the CNS. The DM-20 transcript has previously been reported to be expressed in newborn oligodendrocyte progenitor cells and during embryonic development. We have therefore used a DM-20 cRNA probe to follow, by in situ hybridization, the oligodendrocyte lineage during embryonic development. DM-20-expressing cells were first detected at E9.5 in the ventricular germinal layer of the laterobasal plate of the diencephalon. At E14.5, DM-20+ cells had largely disappeared from the diencephalic ventricular germinal layer and had colonized the ventral mantle layer at the posterior part of the basal diencephalon. Between $\mathrm{E} 17.5$ and $\mathrm{P1}$, the number of $\mathrm{DM}-2 \mathrm{O}^{+}$cells increased and progressively invaded the major white matter tracts. In the hindbrain, DM-20+ ${ }^{+}$cells appeared at E12.5 in the caudal part of the rhombencephalon, and at E14.5 all along the ventral spinal cord. Between E14.5 and $\mathrm{P1}, \mathrm{DM}-20^{+}$cells progressively colonized, first ventrally then dorsally, all the spinal cord and more extensively the white matter tracts. At E14.5, a large gap separated, rostrally, the medullary columns from the mantle layer cells in the prosencephalon, suggesting that oligodendrocytes in the mid- and forebrain originate from a different pool of precursors than in the rhombencephalon and the spinal cord. Together, these observations suggest that expression of the DM-20 transcript is an early marker of commitment to the oligodendrocyte lineage, and that oligodendrocyte precursors originate in a ventrally restricted region.

[Key words: PLP/DM-20 gene, ollgodendrocyte llneage, oligodendrocyte precursor cells, mouse embryogenesis, diencephalic basal plate, in situ hybridization]

\footnotetext{
Received May 16, 1994; revised July 8, 1994; accepted Aug. 12, 1994.

We thank Drs. M. Ruberg, M. Wassef, L. Bally-Cuif, and R. M. AlvaradoMallart for helpful discussions on this manuscript, Dr. W. D. Richardson for sharing data prior to publication, Dr. A. Frankfurter for the gift of TuJ1 antibody, and Dr. P. Crocker for the gift of anti-F4/80 antiserum. S.T. was partially supported by a yrant fronl Assistance Publique-Hopitaux de Paris. This work was partially supported by INSERM, Spanish DGICYT Grant PB90/0296-CO1 to L.P., and grants from the European Leucodystrophy Association, the Ministère de la Recherche et de la Technologie (91.C 0055), and the Association Française contre les Myopathies to B.Z.

Correspondence should be addressed to Dr. Bernard Zalc at the above address.

Copyright $@ 1995$ Society for Neuroscience $\quad 0270-6474 / 95 / 151012-13 \$ 05.00 / 0$
}

Proteolipid protein (PLP) and its isoform DM-20 are produced by alternative splicing of a single gene transcript. In the CNS, these proteins account for more than $50 \%$ of myelin protein (Lees and Brostoff, 1984). They are not constituents, however, of peripheral nervous system (PNS) myelin, although the transcript and the protein are expressed in Schwann cells (Puckett et al., 1987). Mutations of the PLP/DM-20 gene are associated with severe disorders of the CNS, but not the PNS, characterized by abnormal development and premature death of oligodendrocytes and hypomyelination, as in the jimpy mouse (Skoff, 1976; Privat et al., 1982; Knapp et al., 1986; Knapp and Skoff, 1987), or by hypomyelination alone, as in the rumpshaker mutant (Schneider et al., 1992). One or both of these proteins seem, then, to be necessary for the early development of oligodendrocytes, as well as for myelin compaction, but these two functions appear to be dissociable.

PLP begins to be expressed postnatally, during the final stages of oligodendrocyte maturation (Dubois-Dalcq et al., 1986; Monge et al., 1986), too late to explain the abnormal development of oligodendrocytes in the jimpy mutant mouse. We have reported, however, that oligodendrocyte progenitors, purified from newborn rat brain, expressed a transcript hybridizing with a PLP/DM-20 cDNA probe (Lubetzki et al., 1991). Furthermore, DM-20-encoding mRNA has been detected in the mouse by PCR at embryonic day 11 (Ikenaka et al,, 1992) and by in situ hybridization at embryonic day 9.5 (Timsit et al., 1992). These data suggested that products of the PLP gene may, therefore, play a role in glial cell differcntiation.

To approach this question, we have determined the profile of DM-20 expression during development of the mouse from embryonic day 8.5 (E8.5) to postnatal day 1 (P1) by in situ hybridization with a PLP/DM-20 cRNA probe that labels only DM-20 transcripts during the premyelination period. DM-20+ cells first appear at E9.5 in the laterobasal plate of the diencephalon, and extend at E12.5 to other parts of the prosencephalon. At E14.5, isolated labeled cells appear in the ventral mantle layer at these locations. A separate pool of DM-20+ cells was detected, between E12.5 and E14.5, in the rhombencephalon, and at E14.5 in the spinal cord, ventral to the central canal, progressively colonizing the white matter tracts. The DM-20+ cells seen at E14.5 are most probably precursors of oligodendrocyte progenitor cells. This may also be the case for the early (E9.5-E12.5) DM-20-labeled cells. The DM-20 transcript would therefore be an early marker of commitment to this lineage. 

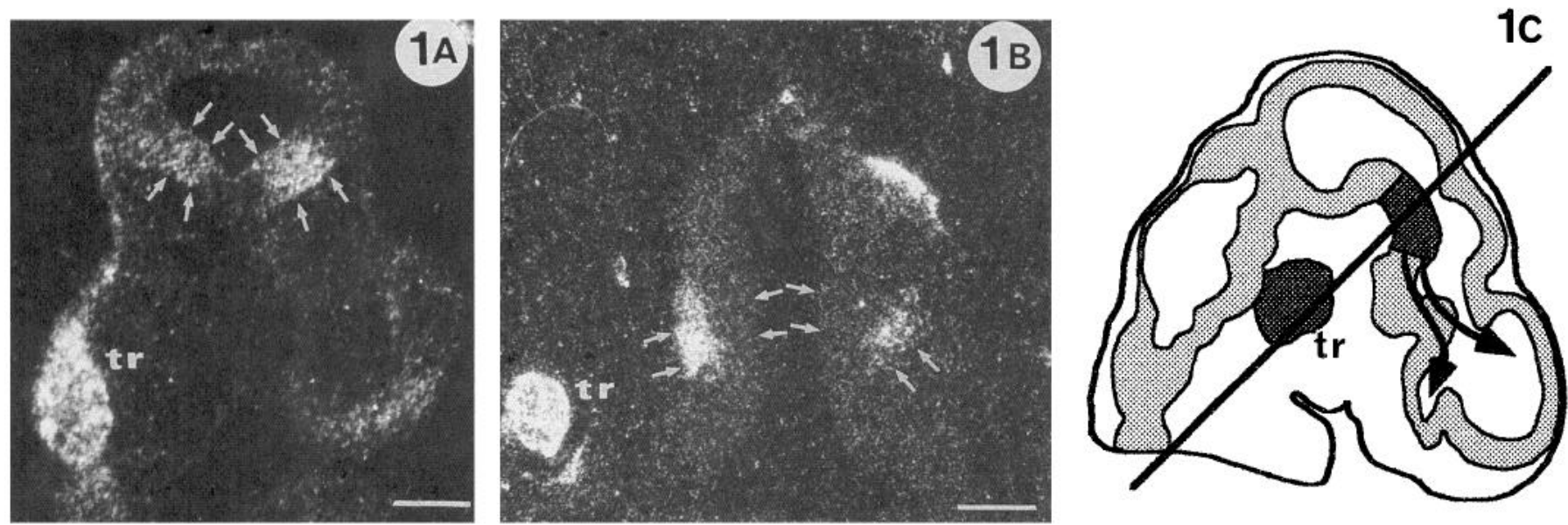

Figure 1. DM-20 ${ }^{+}$cells in frontal sections of E9.5 $(A)$ and E12.5 $(B)$ mouse embryos. Arrows point to DM-20+ ventricular cells in the laterobasal plate of the diencephalon. Note that at E9.5 $(A)$, DM-20+ cells occupied the entire thickness of the germinal layer, while at E12.5 $(B)$, DM-20 ${ }^{+}$ cells disappeared from the ventricular layer and concentrated in the incipient mantle layer. The inset $(C)$ shows the plane of section in $A$ and $B$ and the longitudinal extent of the labeied zone (dark gray). Note the DM-20 expression in the trigeminal ganglion primordium (tr). Scale bars: $A$, $200 \mu \mathrm{m} ; B, 300 \mu \mathrm{m}$.

\section{Materials and Methods}

Animals. Embryos from outbred OF1 mice (IFFA-CREDO, Lyon, France) were taken at E8.5, E9.5, E12.5, E14.5, and E17.5, and postnatal animals at $\mathrm{P} 1$, that is, $1 \mathrm{~d}$ after birth. The average gestation period lasts $19.5 \mathrm{~d}$. The midpoint of the dark interval during which mating occurred was designated as day 0 and the embryos were considered to be $\mathrm{E} 0.5$ on the morning following breeding.

In situ hybridization. Embryos were fixed at $4^{\circ} \mathrm{C}$ by overnight immersion in $4 \%$ paraformaldehyde in $0.12 \mathrm{M}$ phosphate buffer, $\mathrm{pH} 7.4$. At P1, animals were perfused intracardially before immersion in the same fixative. After fixation, tissues were dehydrated and paraffin embedded (Paraplast Plus). Serial sections ( $7.5 \mu \mathrm{m}$ thick) were collected on gelatin chrom-alum-coated glass slides and stored at $4^{\circ} \mathrm{C}$. Sections were processed as in Fontaine and Changeux (1989).

Radiolabeled RNA probes. ${ }^{35} \mathrm{~S}-\mathrm{UTP}$-labeled $(1000 \mathrm{Ci} / \mathrm{mmol}$; Amersham, Les Ulis, France) sense and antisense cRNA probes were transcribed from the pBS-DM-20 plasmid (Timsit et al., 1992) with T7 and T3 RNA polymerase (Pharmacia LKB Biotech., Uppsala, Sweden), respectively, and the reagents of the Riboprobe kit (Promega Corp., Madison, WI). Specific activities of both probes were in the range of 1-1.5 $\times 10^{7} \mathrm{cpm} / \mu \mathrm{g}$ of RNA. Before hybridization, the probes were hydrolyzed for $45 \mathrm{~min}$ in $0.4 \mathrm{M} \mathrm{Na}_{2} \mathrm{CO}_{3}$ at $60^{\circ} \mathrm{C}$ to generate fragments of about 150 bases.

Immunostaining on paraffin sections. Serial $7.5 \mu \mathrm{m}$ sections were collected and alternatively hybridized with the DM- $20{ }^{35}$ S-cRNA probe, or the TuJ1 mouse monoclonal antibody (gift of Dr. Frankfurter) diluted 1:1000 (Easter et al., 1993; Moody et al., 1989) or the anti-F4/80 rabbit polyclonal antiserum (prepared by Drs. P. Dri and S. Gordon) diluted 1:1000. The sections were incubated overnight at $4^{\circ} \mathrm{C}$ with the diluted first antibodies, washed, and incubated with either a fluorescein-labeled goat anti-mouse IgG1 (Southern Biotech) diluted 1:100, or the Vectastain avidin-biotin-peroxidase system (Vector Laboratories).

In situ hybridization and immunolabeling on whole-mount embryos. Hybridization on whole-mount embryos at E12.5 and E14.5 was done as described in Bally-Cuif et al. (1992). Briefly, cRNA probes were labeled with digoxigenin-UTP (Boehringer Mannheim) following the manufacturer's instructions. Embryos were fixed in $4 \%$ paraformaldehyde for $4 \mathrm{hr}$, and the neural tube was dissected from the embryos, gradually dehydrated, and stored at $-20^{\circ} \mathrm{C}$. All the other treatments, including hybridization and detection of probe with anti-digoxigeninalkaline-phosphatase-labeled antibody, were as described (Bally-Cuif et al., 1992). After development of the alkaline phosphatase activity, embryos were incubated overnight at $4{ }^{\circ} \mathrm{C}$ in anti-neurofilament monoclonal antibody (anti-165 kDa, clone $2 \mathrm{H} 3$, DSHB) diluted 1:5000 in PBS containing $0.25 \%$ Triton $\mathrm{X}-100$ and $0.2 \%$ bovine serum albumin. After extensive washes, embryos were incubated with peroxidase-conjugated anti-mouse IgG antibody (Sigma), diluted 1:200, overnight at $4^{\circ} \mathrm{C}$.
Bound antibody was detected by a 20 min incubation in diaminobenzidine tetrahydrochloride (Sigma) and $\mathrm{H}_{2} \mathrm{O}_{2}$ (Merck).

Embryonic cell cultures. Preparation of neural tube cultures have been described elsewhere in detail (Lafont et al., 1993). Briefly, cortex, mesencephalon, diencephalon, ventral, dorsal, and total spinal cord were dissected from mice embryos at E12.5 and E13.5. After removing the meninges, monolayer culture cells were established by mechanical dissociation. Cells were cultivated in a defined medium as described (Lafont et al., 1993), in the absence of any added growth factors. After 4 $\mathrm{d}$ in vitro (DIV) the cells were fixed with $4 \%$ paraformaldehyde and processed for immunodetection, as described (Lafont et al., 1993), using either mouse monoclonal anti-galactosylceramide (GalC) (Ranscht et al., 1982) diluted 1:50 or affinity-purified rabbit polyclonal anti-myelin basic protein (MBP) diluted 1:300 (Allinquant et al., 1991). Specific binding of antibodies was visualized using appropriate fluorescent-conjugated secondary antibodies (Amersham) diluted 1:100.

\section{Results}

The specificity of the antisense probe was tested on sections of adult mouse cerebellum, where the expected pattern of hybridization was observed (Trapp et al., 1987). No signal was detected when adult cerebellar sections or sections from embryonic or postnatal mice (E8.5, E9.5, E12.5, E14.5, E17.5, and P1) were hybridized with the labeled sense DM-20 cRNA (not shown). DM-20 expression could first be detected with the antisense probe at E9.5, both in the neural tube and in neural crest derivatives. During development, DM-20 was expressed in four spatially distinct regions: prosencephalon, brainstem and spinal cord, olfactory system, and neural crest-derived cells. We used the model of Bulfone et al. (1993) and Puelles and Rubenstein (1993) for subdivision and terminology.

\section{Expression of DM-20 transcripts in the prosencephalic region}

Cellular localization. At E9.5, DM-20 expression was restricted to cells in the lateral basal plate of the diencephalon on both sides of the median line (Fig. 1A,C). These cells occupied the entire thickness of the germinal layer. Neither the ventral paramedian zone nor the alar plate were labeled.

At E12.5, DM- $20^{+}$cells disappeared from the ventricular layer and concentrated in the incipient mantle layer (Fig. 1B). On serial sagittal sections, DM- $20^{+}$cells extended from the laterobasal plate of the diencephalon along two axes (Fig. 2). First, a 

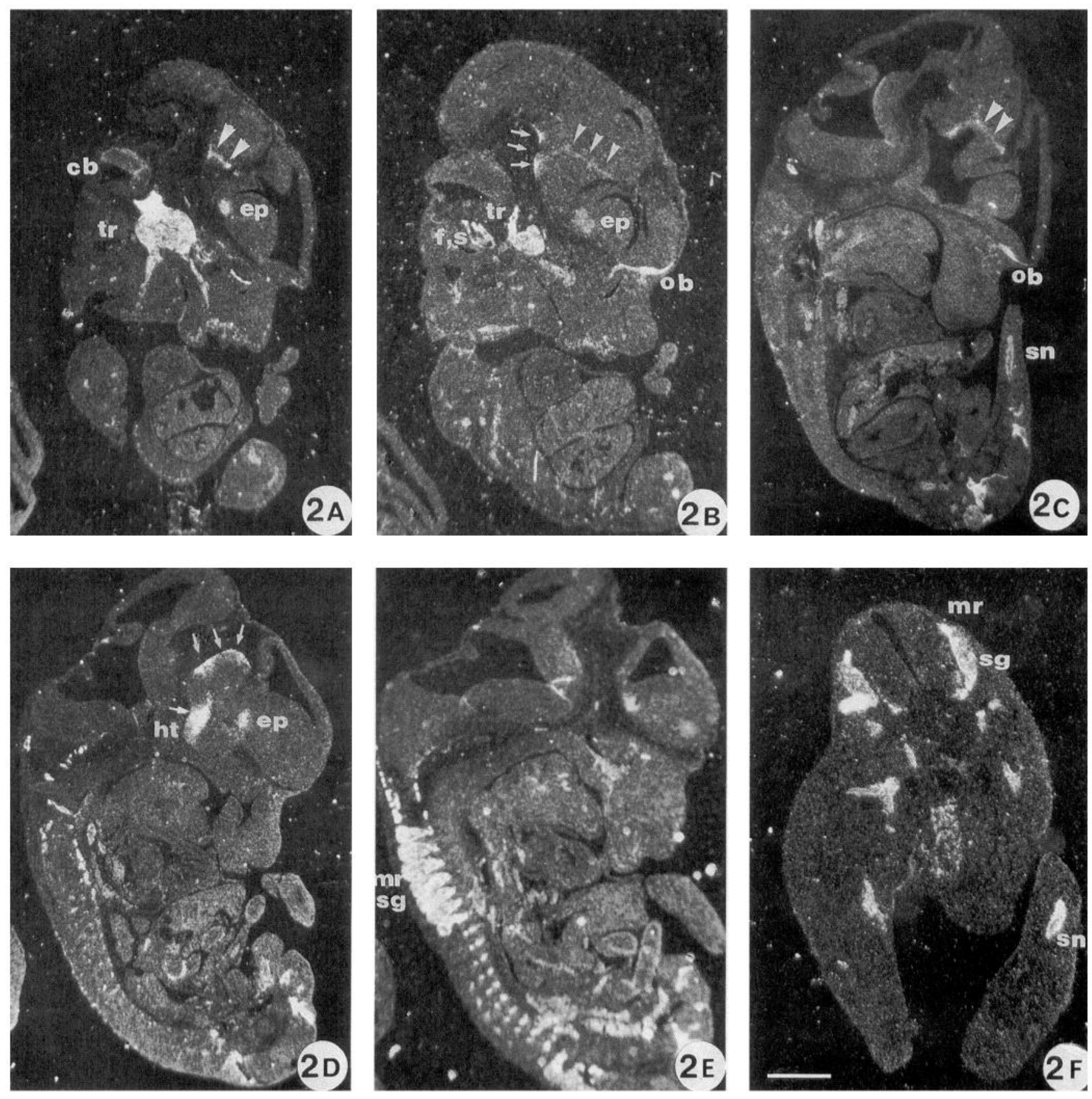

Figure 2. DM-20+ cells in sagittal sections of E12.5 mouse embryos $(A-E)$ and a cross section at the level of the leg limb buds $(F)$. The sagittal sections are slightly oblique. $A$, Lateral on one side of the embryo; $B$ and $C$, near to the midline; $D$ and $E$, more lateral on the other side of the embryo. Small arrows in $B$ and $D$ point to the DM- $20^{+}$domain in the diencephalic and hypothalamic (ht) basal plate (best seen in $D$ ). Arrowheads in $A-C$ point to a linear transverse domain at the P2/P3 interprosomeric boundary (zona limitans intrathalamica). DM-20 mRNA is also expressed in the entopeduncular area $(e p) . c b$, cerebellum. Note that DM-20 mRNA is also detected in peripheral territories such as the trigeminal ganglion $(t r)$, the facial $(f)$ and statoacoustic $(s)$ nerves, the olfactory blastema $(o b)$, the motor roots $(m r)$, the spinal ganglia $(s g)$, and the spinal nerve $(s n)$. Scale bar, $1 \mathrm{~mm}$.

narrow line of radially aligned cells extended dorsally from the region of the posterior tuberculum, dividing the posterior and the anterior thalamus at the $\mathrm{P} 2 / \mathrm{P} 3$ interprosomeric boundary (arrowheads in Fig. $2 A-C$ ). The second axis extended rostrally from the basal plate of the diencephalon, along the basal plate of the hypothalamus (mammillary and tuberal regions), which was intensely labeled and remained so until Pl (Figs. 2D, 3A,C).
The number of positive cells was greater along this second axis than along the $\mathrm{P} 2 / \mathrm{P} 3$ interprosomeric boundary (compare Fig. 2, $D$ and $A-C$ ). This basal hypothalamic domain also respected the ventral paramedian zone (Fig. $2 C$ ). In addition, a separate patch of labeling appeared in the anterior entopeduncular area adjacent to the medial ganglionic eminence in the basal telencephalon (Fig. $2 A, B, D, E$ ). 
At E14.5, DM-20+ cells had largely disappeared from the diencephalic ventricular germinal layer, but distinctly labeled cells were observed some distance away from the ventricular lumen, in the mantle layer (subventricular zone), at the posterior part of the basal diencephalon outside a halo of densely packed cells surrounding the third ventricle (Fig. 3B).

At E17.5, the number of DM-20-expressing cells had significantly increased along the external layer of the mantle zone and some DM-20 cells were already seen inside, or in the close vicinity, of the major fiber bundles (not shown).

At P1, DM-20 expression was clearly seen in the eminentia media at the level of the third ventricle and in tracts such as the medial forebrain bundle (Fig. $3 D$ ). In the telencephalon, DM$20^{+}$cells were observed in the supralenticular internal capsule and the subcortical white matter, extending dorsomedially toward the corpus callosum and ventrolaterally along the capsula extrema, deep into the piriform cortex (Fig. $3 E$ ). On more rostral sections, at the level of the lateral ventricles, DM-20+ cells were also seen in the subventricular layer (not shown).

Characterization of $\mathrm{DM}-20^{+}$cells in the prosencephalic region

To characterize the type of cells expressing DM-20, sections adjacent to those hybridized with the DM-20 probe were immunostained with the TuJ1 antibody, which is specific for neuron class III $\beta$-tubulin, or with anti-F4/80 polyclonal antiserum, which is specific for macrophages and microglial cells.

At E12.5, labeling with anti-F4/80 antibody (Fig. 4C) showed a scattered pattern of staining, without any definite spatial distribution, illustrating the small number of macrophages present in the neural tube at this age. In particular, the presence of macrophages in the $\mathrm{DM}-20^{+}$area was aleatory. The comparison of distribution of neuronal cell bodies and DM-20 cells was performed on alternate serial sections. Neuronal cell bodies $\left(\mathrm{TuJl}^{+}\right)$were always found on the external margin of the germinal layer (Fig. $4 B$ ). The group of DM-20 cells was located in a more internal and dorsal position than the neuronal cell bodies (Fig. $4 A$ ). The most ventral and external portion of the DM-20+ $0^{+}$group of cells overlapped, however, with the most dorsally and internally localized neurons. To better characterize the DM-20+ cells, double labeling was performed on wholemount embryos with DM-20 digoxigenin cRNA antisense probe and anti-neurofilament antibodies (Fig. 5). The morphology of $\mathrm{DM}-20^{+}$cells in the laterobasal plate of the diencephalon (Fig. $5 A, B$ ) appeared to be different from that of the hypothalamic group of DM-20+ cells, which were also more intensely labeled (Fig. $5 A, D$ ). No neurofilament-positive neurites were seen to emerge from the DM-20 groups of cells. In the $\mathrm{P} 2 / \mathrm{P} 3$ interprosomeric boundary, DM- $20^{+}$cells appeared as a double layer of closely apposed neurofilament-negative cells (Fig. $5 \mathrm{C}$ ).

\section{Expression in the caudal rhombencephalon and spinal cord}

The first DM-20+ cells were observed at E12.5 in the caudal rhombencephalon and at E14.5 in the spinal cord. A large gap separated the rhombencephalic DM- $20^{+}$cells from the mantle cells in the diencephalon, as shown by the absence of labeling on a series of frontal serial sections from the caudal part of the diencephalon to the rostral part of the rhombencephalon (Fig. 6A).

At $\mathrm{E} 14.5, \mathrm{DM}-20^{+}$cells were localized in the ependymal layer of the spinal cord, in contact with the lumen. The DM20 signal was restricted to the ventral basal region. No positive cells were seen in the floor plate. These DM-20+ cells formed two sparse columns on either side of the central canal (Fig. $7 A, B$ ), and could be followed throughout the pons (Fig. 6A), the medulla oblongata (Fig. $6 C$ ), and along the spinal cord, where DM-20 mRNA seemed to be expressed simultaneously at all levels of the rostrocaudal axis. In the spinal cord, the two columns of DM- $20^{+}$cells consisted of a single layer of cells (Fig. $7 A$ ). In the medulla oblongata, however, DM- $20^{+}$cells were more numerous, and some were located at a short distance from the ventricular zone (Fig. $6 \mathrm{C}$ ).

From E14.5 to Pl, the clusters of $\mathrm{DM}-20^{+}$cells disappeared from the ventricular zone, and were found scattered throughout the white and gray mattcr, cxtcnding dorsally and colonizing progressively the brainstem and the spinal cord (Fig. $6 B$ ).

At P1, DM-20 $0^{+}$cells had almost completely invaded the brainstem (Fig. 6D) and the spinal cord (Fig. 7D). In the upper brainstem, DM- $20^{+}$cells preferentially colonized the ventral tegmentum (pons), superficial tracts like the descending trigeminal nerves, and the deep white matter of the cerebellum (Fig. 6D). In the spinal cord, the ventral marginal layer was intensely labeled and only the superficial laminae of the dorsal horns were devoid of DM-20+ cells (Fig. 7D).

At E14.5, no overlap was seen between cells labeled by the DM-20 probe, or the TuJ1 and anti-F4/80 antibodies, as shown for the pons, on serial frontal sections of the rostral rhombencephalon (Fig. $4 D-F$ ). Immunolabeling of serial spinal cord sections with TuJ1 antibody showed an absence of colocalization of DM-20+ $0^{+}$cells with neuronal cell bodies (Fig. $6 E$ ). Similarly, microglial cells, labeled with the anti-F4/80 antiserum, never colocalized with DM-20+ $0^{+}$cells (data not shown).

\section{Regional differentiation of neural tube in culture}

Assuming that DM-20 is an early marker of oligodendrocyte progenitors, and taking into account the selective regional pattern of expression of DM-20 at E12.5, we tested the potential of various regions of the neural tube to generate oligodendrocytes. Cultures were derived from different regions of neural tubes from E12.5 and E13.5 mouse embryos. To accelerate the differentiation of putative oligodendrocyte precursors, no growth factors were added to the defined culture medium (Richardson et al., 1988). Under our culture conditions, the vast majority of the cells were differentiating neurons (Lafont et al., 1993). However, as shown in Table 1, in some of the regions analyzed $\mathrm{GalC}^{+}, \mathrm{MBP}^{+}$cells were observed. These cells had the typical multiprocess morphology of mature oligodendrocytes (not shown) (Lubetzki et al., 1993). Oligodendrocytes were observed only in cultures derived from diencephalon and ventral spinal cord, two regions of the neural tube expressing DM-20, but never in cultures derived from cortex, mesencephalon, or dorsal spinal cord, which did not express DM-20 between E12.5 and E14.5. Similar data were obtained with both E12.5 and E13.5 embryos.

\section{The olfactory system}

At E12.5, on sagittal sections, a linear signal was detected ventral to the telencephalon, in the olfactory blastema and the olfactory tracts (Fig. 2B,C). At E14.5, afferent fibers from both the lateral and the vomeronasal regions were labeled, as well as the olfactory epithelium in the nasal fossae (Fig. 8A); no signal, however, could be detected in the vomeronasal organ per se. In addition, at E14.5, a restricted zone in the medial amygdala was also DM-20+ (Fig. $3 C$ ), but no signal was de- 

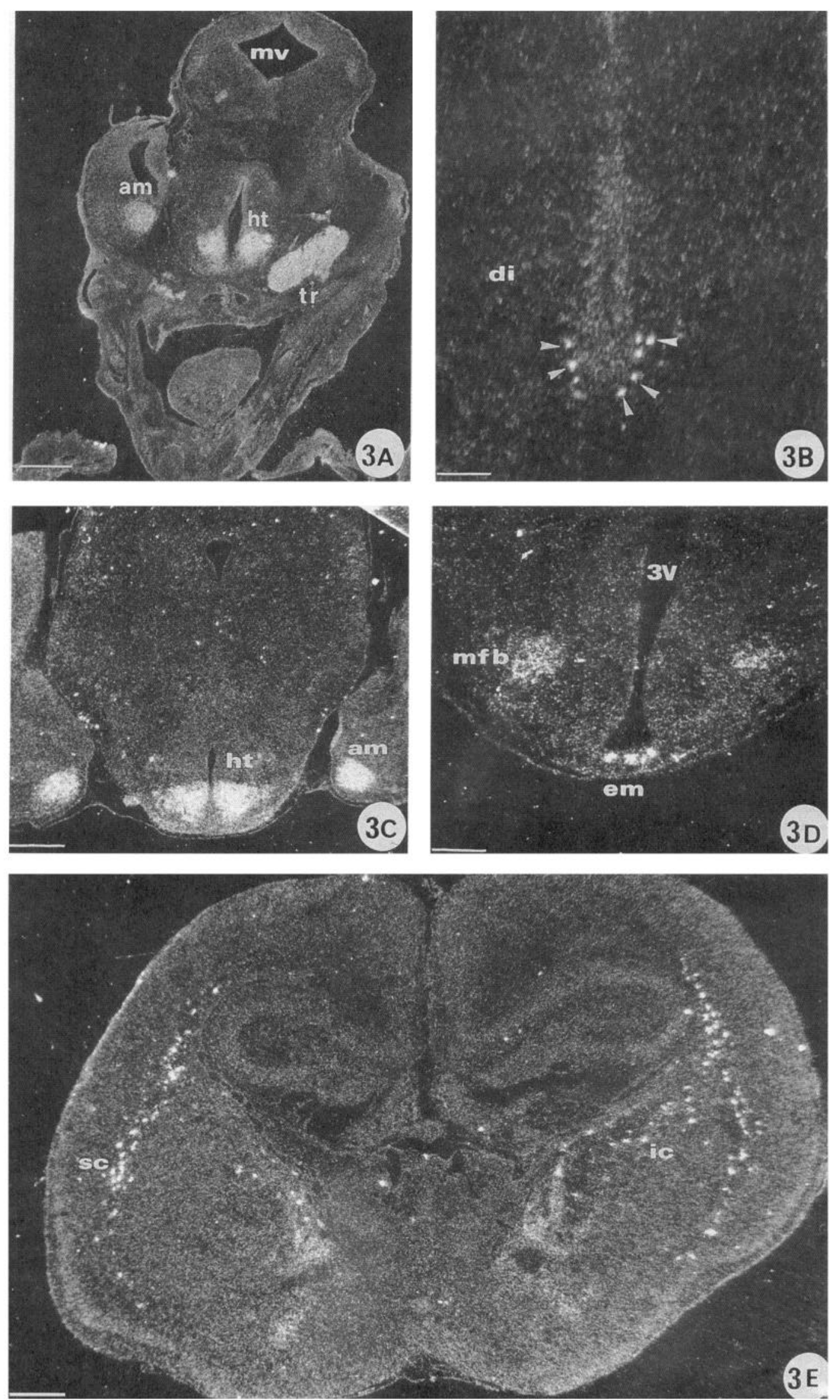
tected in the inner layer of the olfactory bulb, indicating that the secondary olfactory neurons did not express DM-20 transcripts. At E17.5 and Pl (Fig. 8B), DM-20 labeling of the olfactory system remained unchanged, with the exception of the olfactory epithelium in the nasal fossac where the signal had disappeared.

\section{Neural crest derivatives}

DM-20 cells were observed from E9.5 onwards in neural crest derivatives such as the trigeminal ganglion (Fig. 1A). At E12.5, the trigeminal ganglion and its three roots were intensely labeled, as were the facial and statoacoustic nerves (Fig. $2 A, B$ ). DM-20 transcripts were also detected in some cells of the spinal ganglia, in the sensory and motor roots, and in the sympathetic prevertebral and perivascular ganglia (Fig. $2 E, F$ ). In the spinal ganglia, not all the cells expressed the DM-20 transcript. This was confirmed by bright-field microscopy (data not shown). A linear DM-20 signal was also detected along the pathways of the peripheral nerves in the limb buds and the tail (Fig. $2 F$ ). The signal was confined to the perikarya of cells lying along the axons, suggesting that they were Schwann cells or their precursors. In older animals, expression of the DM-20 transcript persisted in the PNS, in the spinal ganglia, for example (Fig. 7A).

\section{Discussion}

Our findings raise several questions concerning the role of DM20 as a marker of the oligodendrocyte lineage, the possible early commitment of a subset of celts as prccursors of oligodendrocyte progenitors, and finally the role of DM-20 as a general marker of all ensheathing glial cells: oligodendrocytes, Schwann cells, and the ensheathing cells of the olfactory tract.

\section{Specificity of the $D M-20$ probe}

Although the DM-20 cRNA probe used in the present study would hybridize with PLP transcripts as well as with its alternatively spliced isoform DM-20, it may be assumed that the mRNA detected by in situ hybridization in embryonic brain belongs solely to the DM-20 species, since the longer PLP isoform cannot be detected before birth (Ikenaka et al., 1992; Timsit et al., 1992). Furthermore, the nuclentide sequence of RT-PCR products from E13 brain RNA, amplified with primers corresponding to exons 1 and 7 of the PLP/DM-20 cDNA, was shown to correspond solely to DM-20 message (Timsit et al., 1992). Recently, a family of gencs rclated to PLP/DM-20 have been identified in the shark, the ray (Kitagawa et al., 1993), and the mouse (Yan et al., 1993). In our study, we cannot exclude that the DM-20 cRNA probe cross-hybridized with another member of the PLP/DM-20 family. This possibility appears rather unlikely, however, since the patterns of hybridization obtained with murine cRNA probes corresponding to other members of this family were different than that of the PLP/ DM-20 cRNA (Yan et al., 1993; C. Lagenaur, personal communication).
DM-20 as an early marker of the oligodendrocyte lineage?

In the prosencephalon. Isolated DM- $20^{-}$cells appeared in the subventricular zone at F,14.5 in the caudal diencephalon. The number of these cells increased dramatically from E14.5 and were found in the future myelinated tracts at P1. At this point, it is not possible to distinguish between DM-20 in cells that migrate and proliferate, or the induction of DM-20 in cells already present in a given area. There are arguments suggesting that DM-20 - cells in the mantle zone represent oligodendrocyte progenitors. First, it is generally agreed that oligodendrocyte precursors arise from this zone and migrate into and through the nearby white and gray matter, as shown at the ultrastructural level by Privat and Leblond (1972) using ${ }^{3} \mathrm{H}$ thymidine incorporation. More recently, Levine and Goldman (1988), using a variety of antibodies to label immature neuroectodermal cells and developing oligodendrocytes in several areas of the rat $\mathrm{CNS}$, also concluded that oligodendrocytes in the forebrain arise from the subventricular (mantle) zone. In this respect, it was of particular interest to observe at P1 DM-20 cells in the forebrain subventricular zone. Second, a transcript of the PI.P gene was detected in oligodendrocyte progenitor cells by Northern blot analysis (Lubetzki et al., 1991). This transcript was probably DM-20 mRNA, since it has been shown that PLP mRNA is not expressed prenatally (Ikenaka et al., 1992; Timsit et al., 1992). Third, the diencephalic DM-20' cells are probably glial cells, since we have not been able to show colocalization with neuronal or microglial markers (Figs. 4, 5). Taken together, these data suggest that the DM-20 cells detected in the mantle layer at E14.5, and which progressively invade the major white matter tracts, belong to the oligodendrocyte lineage.

At this stage, however, we cannot affirm that the cells expressing DM-20 at E14.5 are all oligodendrocyte progenitors. Although we have not observed colabeling of DM-20+ cells with neuronal markers. we cannot exclude the possibility that some of these DM-20- cells might belong to a subpopulation of neurons which do not express the markers used in the present study. Alternatively, it is also possible that some of the cells expressing DM-20 at E14.5 are still pluripotent progenitors, since the generation of neurons and oligodendrocytes from a common precursor cell has been reported by Williams et al. (1991). Similarly, de Vitry et al. (1980) also reported that, until $\mathrm{P} 10$ in the mouse, pluripotential progenitor are present in the hypothalamus. This latter finding is in agreement with our observation of a hypothalamic pool of DM-20-expressing cells from E12.5 to $\mathrm{Pl}$.

In the rhombencephalon and the spinal cord. Cells expressing DM-20 were first observed in the ventricular zone of the brainstem at EI2.5 and in the spinal cord at E14.5. A similar temporal lag in the rostral to caudal direction during development of the spinal cord has previously been reported (Nornes and Das, 1974; Altman and Bayer, 1984). After E14.5, the number of DM-20+ cells increased, appearing outside the ven-

\section{$\leftarrow$}

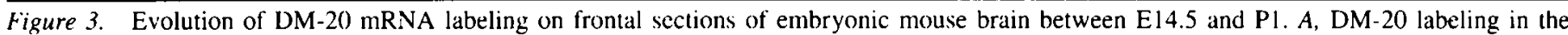

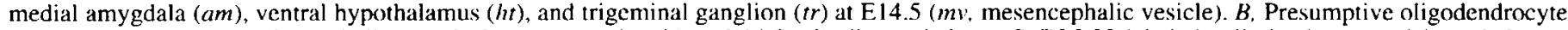

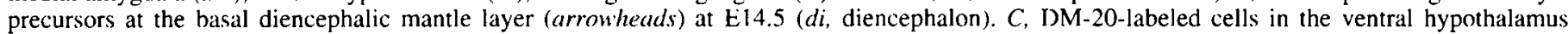

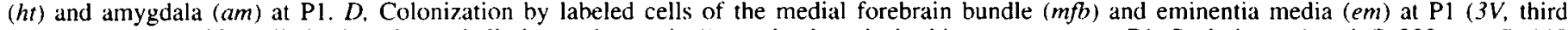

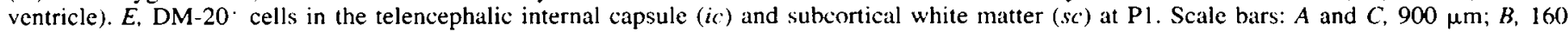
$\mu \mathrm{m} ; D, 260 \mu \mathrm{m} ; E, 6(x) \mu \mathrm{m}$. 

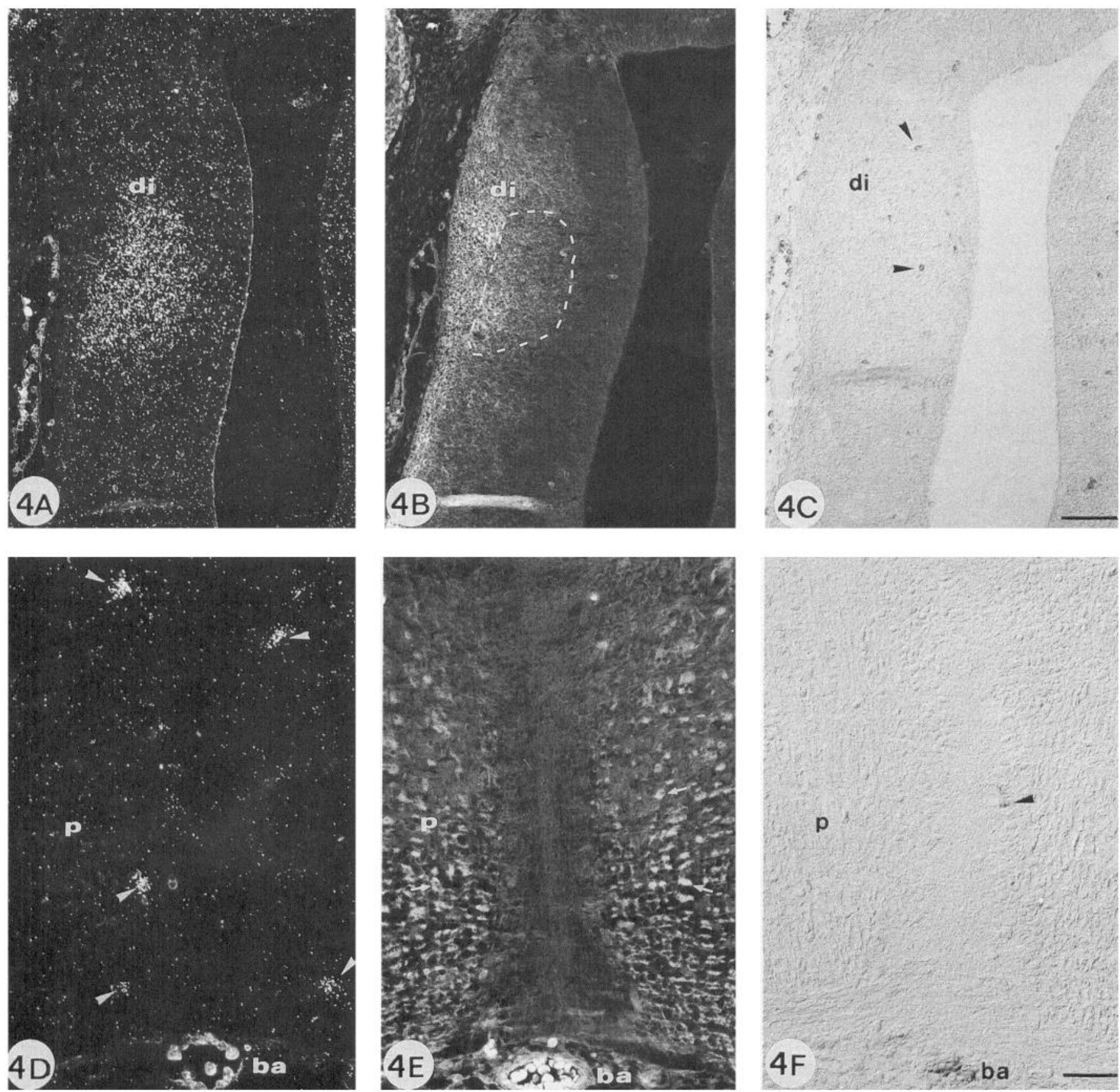

Figure 4. Patterns of expression of DM-20+, neuronal, and microglial markers. Semiadjacent serial frontal sections of E12.5 $(A-C)$ or E14.5 $(D-$ $F$ ) were treated with DM-20 ${ }^{35}$ S-UTP-labeled cRNA probe $(A, B)$, neuron-specific TuJ1 antibody $(B, E)$, or microglial-specific anti-F4/80 polyclonal antiserum $(C, F)$. DM-20 labeling was revealed by autoradiography, TuJ1 antibody by indirect immunofluorescence, and anti-F4/80 antibodies with a peroxidase-conjugated anti-rabbit antibody. For E12.5 embryos, the plane of section was similar to the one shown in Figure $1 C$. Dotted line in $B$ represents the region of DM-20+ cells shown in $A$. Note the partial regional overlap between the territory occupied by DM-20 $0^{+}$cells $(A)$ and $\mathrm{TuJ}^{+}$neurons $(B)$. At E14.5, DM- $20^{+}$cells (arrowheads in $D$ ) in the ventral pons did not colocalize with TuJ $1^{+}$neuronal cell bodies $(s m a l l$ arrows in $E$ point to some of the TuJ1 ${ }^{+}$cells). Microglial cells (arrowheads in $C, F$ ) never colocalized with DM-20 cells. ba, basilar artery; di, diencephalon; $p$, pons. Scale bars: $A-C, 90 \mu \mathrm{m} ; D-F, 50 \mu \mathrm{m}$.

tricular zone in the gray and white matter of the spinal cord following a ventrodorsal gradient, and colonizing the spinal cord almost completely at P1.

The longitudinal columns of $\mathrm{DM}-20^{+}$cells observed at E14.5, which do not overlap with neuronal and microglial markers, are probably the oligodendrocyte progenitors of the spinal cord and the medulla oblongata (Fig. 9). In two recent studies, Warf et al. (1991) and Noll and Miller (1993) demonstrated that oligodendrogenesis occurred only at E14.5 and E16.5 from the ventral region along the rostrocaudal axis of the spinal cord. The dorsal region of the thoracic and lumbar spinal cord developed this capacity later. These authors therefore suggested that commitment to the oligodendrocyte lineage occurred in a specific population of ventrally located glial pre- 

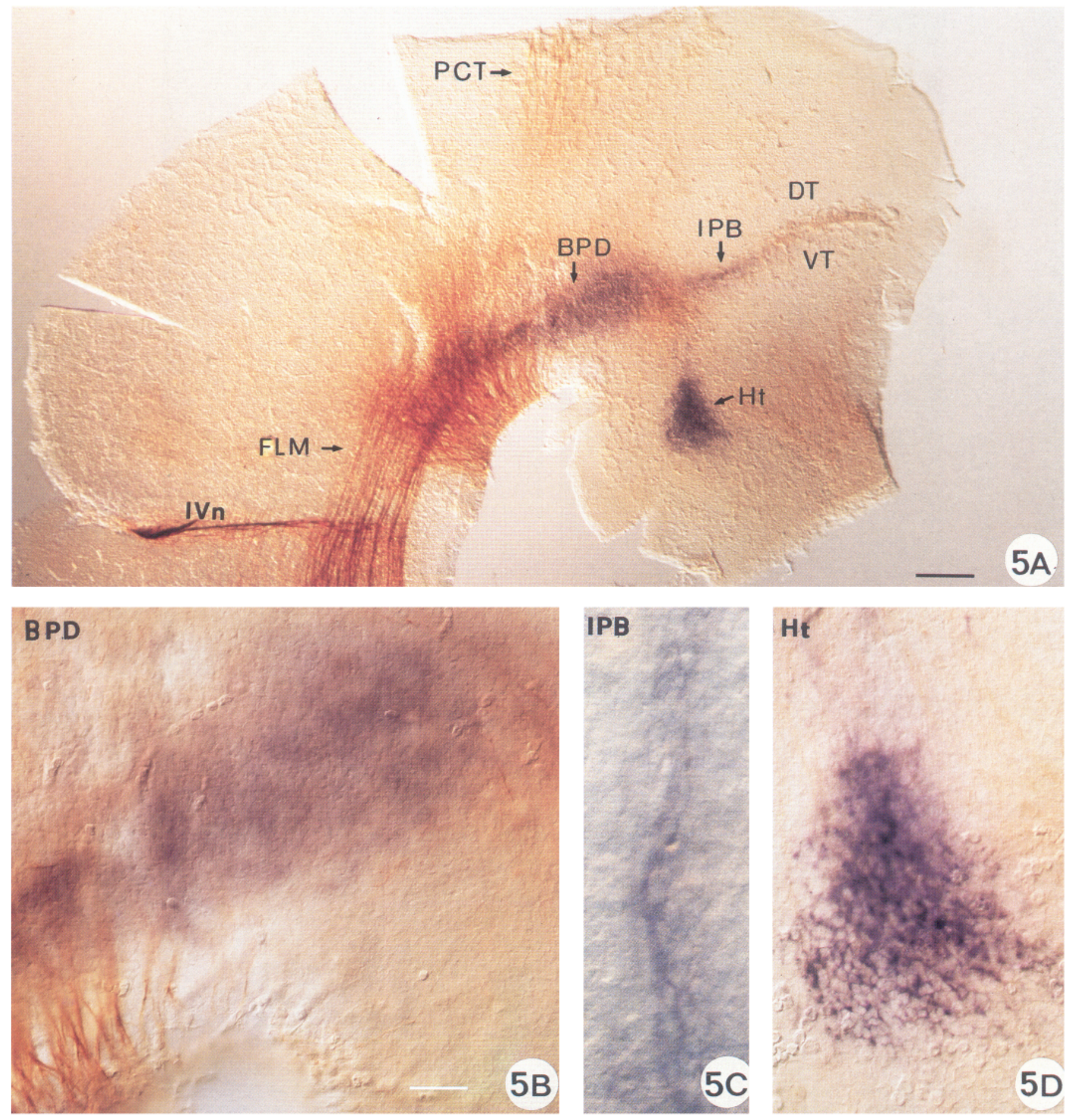

Figure 5. Whole-mount analysis of DM-20 in situ hybridization and anti-neurofilament immunolabeling. Flat-mount of E12.5 embryo is oriented rostral end toward the right side. Embryos were hybridized with digoxigenin-labeled DM-20 cRNA probe and immunolabeled with anti-165 kDa neurofilament antibody (brown). DM- $20^{+}$cells (purple) are seen in the hypothalamus $(H t)(A, D)$, the basal plate of the diencephalon $(B P D)(A$, $B)$, and the $\mathrm{P} 2 / \mathrm{P} 3$ interprosomeric boundary $(I P B)$ zona limitans between the ventrothalamic $(V T=\mathrm{P} 3)$ and the dorsothalamic $(D T=\mathrm{P} 2)$ prosomers $(A, C)$. FLM, fasciculus longitudinalis medialis; $I V n$, trochlear nerve; $P C T$, posterior commissure tract. Scale bars: $A, 200 \mu \mathrm{m} ; B-D, 20 \mu \mathrm{m}$.

cursors in the embryonic spinal cord. In the present study, we also compared the fate of cultures derived of ventral and dorsal spinal cord from E12.5 or E13.5 mouse embryos. Oligodendrocytes were observed only in the cultures derived from the ventral spinal cord and never from the dorsal spinal cord (Table 1). Our data are in agreement with those previously reported by Wharf et al. (1991) in the rat. The longitudinal columns of PDGF- $\alpha$-receptor-positive cells observed by Pringle and Richardson (1993) in the ventral half of the spinal cord on each side of the central canal, which appeared to proliferate and subsequently disseminate throughout the spinal cord, were also thought to include the earliest precursors of the oligodendro- 

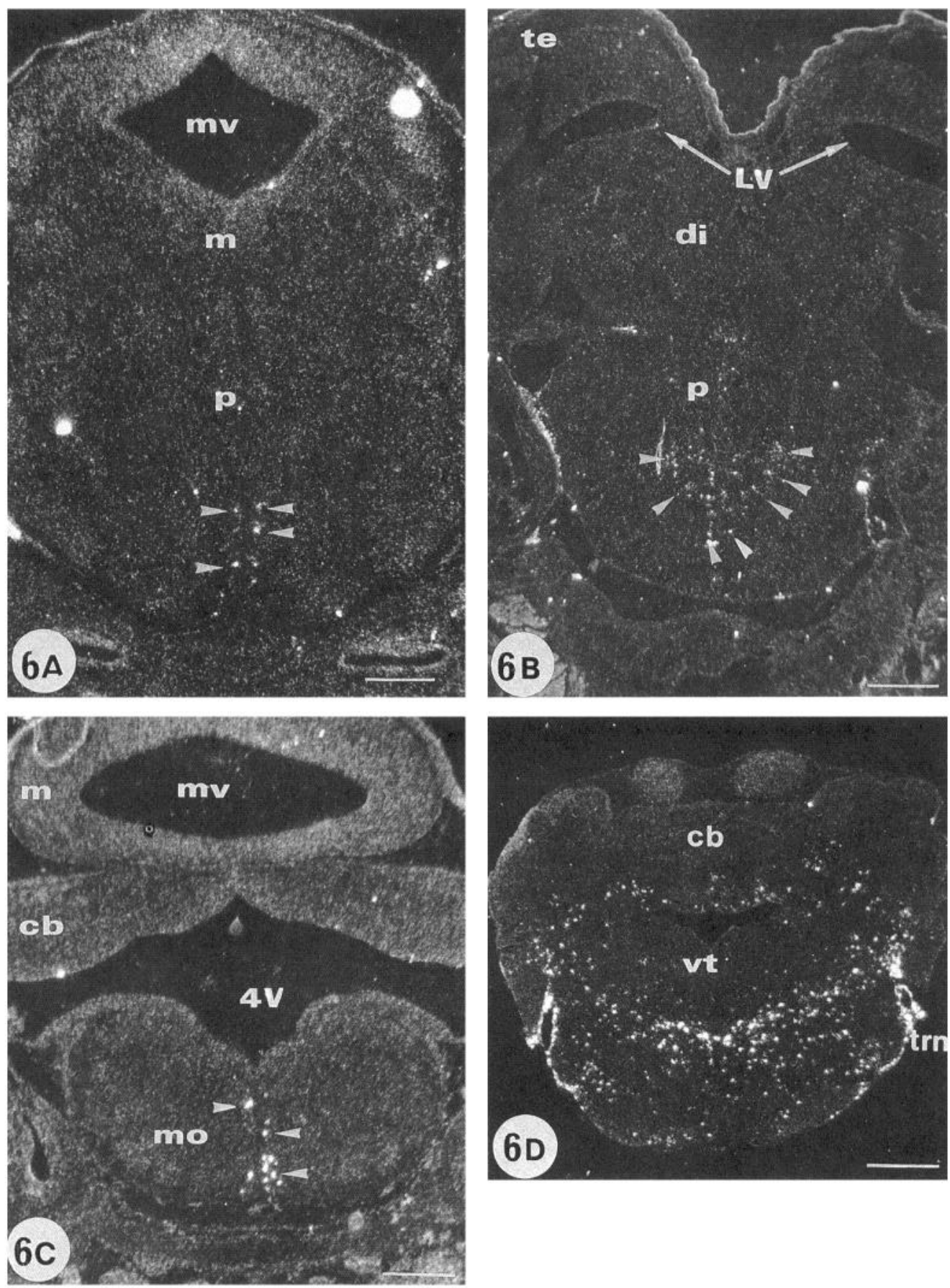

Figure 6. Evolution of DM-20 mRNA labeling in the mouse embryo rhombencephalon between E14.5 and P1. A, Frontal section through the pons and the mesencephalon at E14.5. Presumptive DM-20+ oligodendrocyte precursors (arrowheads) are located in the ventral pons $(p)$. Note the absence of labeling in the mesencephalon $(m) . B$, Frontal section through the pons $(p)$, diencephalon $(d i)$, and telencephalon $(t e)$ at E17.5. Note the increased number of DM-20+ cells (arrowheads) in the pons. $C$, Frontal section through the medulla oblongata (mo), cerebellum $(\mathrm{cb})$, and mesencephalon $(m)$ at E14.5. DM- $20^{+}$cells (arrowheads) are seen at or near the basal plate of the medulla oblongata. D, Transverse section across the upper brainstem and cerebellum at P1. Note the extension of the territory of DM- $20^{+}$cells in the ventral tegmentum ( $\left.v t\right)$ and the deep white matter tract of the cerebellum $(c b) . L V$, lateral ventricle; $m v$, mesencephalic vesicle; $t r n$, trigeminal nerve. Scale bars: $A$ and $C, 400 \mu m ; B, 1000$ $\mu \mathrm{m} ; D, 360 \mu \mathrm{m}$.

cyte lineage. O2-A cells, the immediate precursors of oligodendrocytes, express both the PDGF- $\alpha$-receptor (Hart et al., 1989; McKinnon et al., 1990) and the PLP/DM-20 transcripts (Lubetzki et al., 1991). Therefore, it is not unlikely that the DM- $20^{+}$cells in the ventral spinal cord may be regarded as precursors of oligodendrocytes.
It has been proposed that, in the spinal cord, both astrocytes and oligodendrocytes differentiate directly from embryonic radial glial cells (Choi and Kim, 1983; Choi et al., 1985; Hirano and Goldman, 1988), and would therefore share a common precursor. From the work of Warf et al. (1991), Pringle and Richardson (1993), and the present study, it seems likely that 

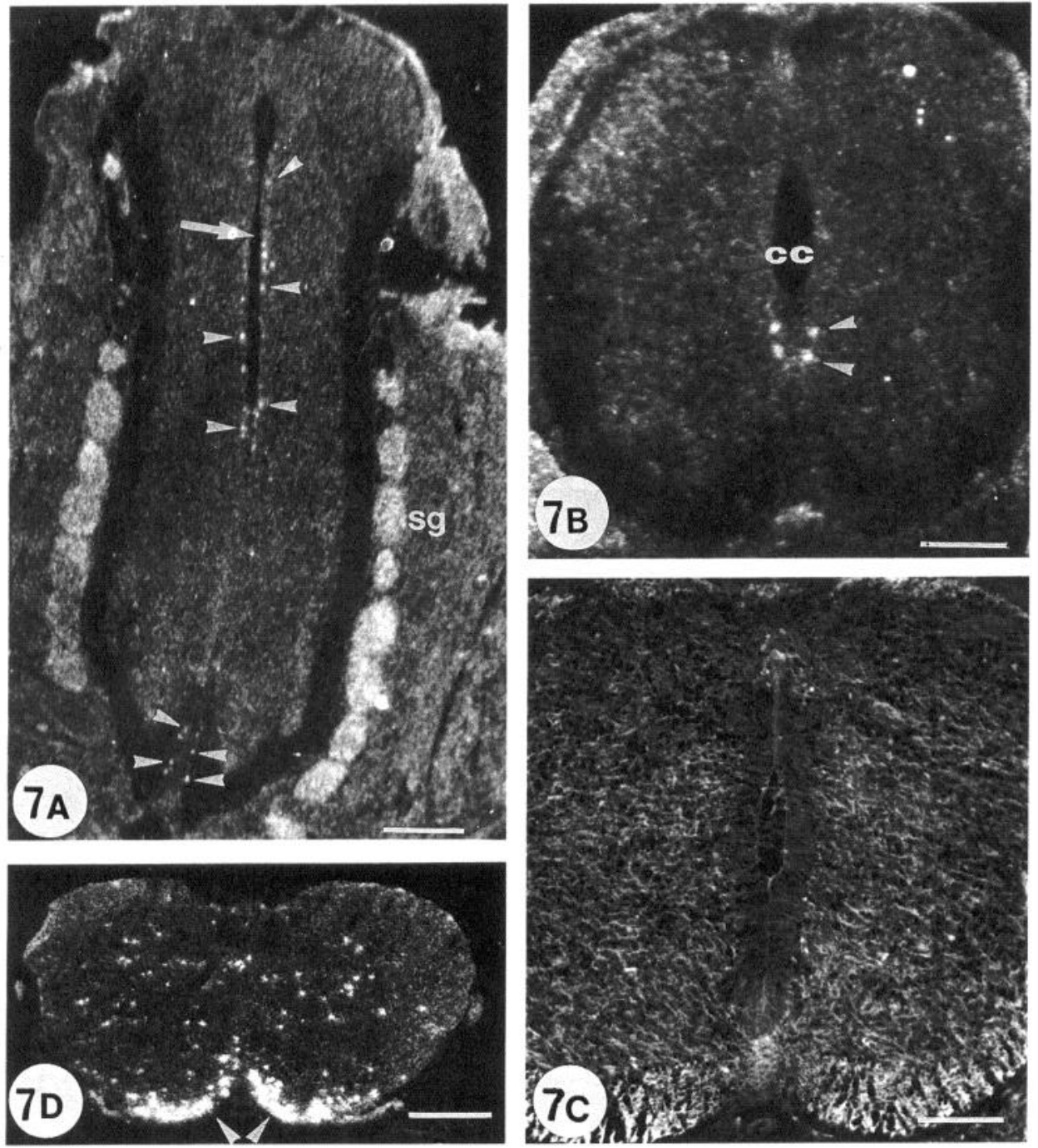

Figure 7. Evolution of DM-20 mRNA labeling in the mouse spinal cord between E14.5 and P1. A. Frontal section through the spinal cord at E14.5. DM-20-labeled cells (arrowheads) are seen as a double column on either side of the central canal even in the most caudal part (arrow points to the lumen of the central canal). Note the labeling of the spinal ganglia $(\mathrm{sg})$. The section is oriented rostral to the top and caudal to the bottom. $B$ and $C$, Semiadjacent semioblique transverse sections of the spinal cord at E14.5 treated with DM-20 ${ }^{35} \mathrm{~S}$-UTP-labeled cRNA probe $(B)$, and neuron-specific TuJ1 antibody $(C)$. DM- $20^{+}$cells (arrowheads) are located in the ventral region of the spinal cord $(B)$ and do not colocalize with TuJ1-labeled neuronal cell bodies $(C) . D$, Transverse sections showing postnatal $(P I)$ DM-20* cells in the spinal cord. Note the intense labeling in the superficial ventral tracts (arrowheads). In $B-D$, ventral is to the bottom and dorsal to the top. Scale bars: $A, 400 \mu \mathrm{m} ; B-D, 1000 \mu \mathrm{m}$.

the radial glial cells in the dorsal region of the spinal cord are not the immediate precursors of oligodendrocytes. If oligodendrocytes do develop directly from radial glia. this transformation may occur only in the radial glial cells of the ventral spinal cord. The present data do not indicate whether the DM-20+ cells at the ventricular surface are already committed to the exclusive production of oligodendrocytes, or if they still are pluripotent precursors cells with the capacity to give rise to

\section{Table 1. Percentage of oligodendrocytes that developed from different regions of E12.5 mouse embryo neural tube in culture}

Neural tube regions

$\%$ Oligodendrocytes

\begin{tabular}{ll}
\hline Cortex & 0 \\
Diencephalon & $0.8 \pm 0.1$ \\
Mesencephalon & 0 \\
Dorsal spinal cord & 0 \\
Ventral spinal cord & $4.2 \pm 0.5$ \\
Total spinal cord & $3.0 \pm 0.3$ \\
\hline
\end{tabular}

Oligodendrocytes were defined as $\mathrm{MBP}^{-}$or $\mathrm{GalC}^{*}$ cells. $\%$ is the ratio of oligodendrocytes to the number of differentiated neurons present in the culture $\times 100$. About 1500 cells were counted on each coverslip. The results are expressed as means \pm SD of cell counts from at least two different coverslips in two to five separate experiments. astrocytes in addition to oligodendrocytes. Miller and Szigeti (1991) found evidence for the production of several different types of astrocytes in the developing rat spinal cord, although it is not yet known whether any of these express DM-20.

\section{Early commitment to the oligodendrocyte lineage in the prosencephalon?}

Whereas the cells that express DM-20 at E14.5 probably belong to the oligodendrocyte lineage, this is less clear for the DM-20-cxpressing cells that appear earlier, from E9.5 to E12.5. In a recent study, Pringle and Richardson (1993) observed that at E13 a group of cells, located in the ventricular and mantle zone in the ventral region of the diencephalon, which express mRNA for the PDGF- $\alpha$-receptor, radiated out into the developing thalamus and hypothalamus (E14-E15) and then into more dorsal regions, including the cerebral cortex (E18-P0). They suggested that all forebrain oligodendrocytes might therefore develop from precursor cells that migrate from a specialized region in the ventricular zone of the diencephalon. DM20 was clearly evident in cells accompanying early differentiated tracts, like the posterior commissure, that will become myelinated. The laterobasal plate of the diencephalon and hypothalamus might therefore contain the pool of glioblasts which will later differentiate into oligodendrocytes in the 

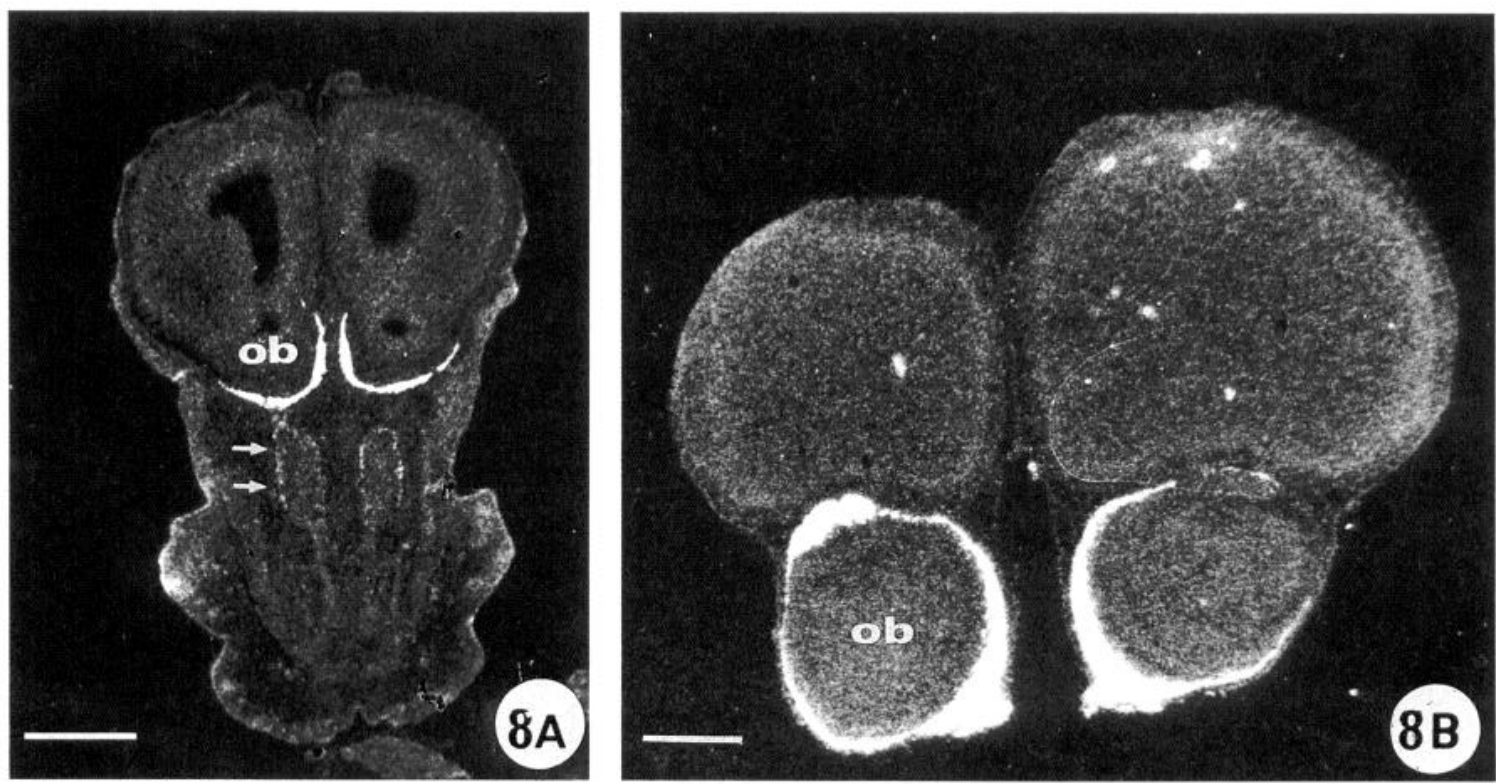

Figure 8. Expression of DM-20 mRNA in the olfactory system. A, Labeling in the superficial axonal layers of the olfactory bulb (ob) and associated cells in the olfactory nasal epithelia (arrows) at E14.5. B, Olfactory bulbs at P1. Scale bars: $A, 900 \mu \mathrm{m} ; B, 750 \mu \mathrm{m}$.

forebrain and the midbrain (Timsit et al., 1992). This hypothesis is schematically represented in Figure 9 and is supported by our in vitro experiments. Indeed, we studied the potential for oligodendrocytes to be generated in cultures derived from different brain regions taken from E12.5 or E13.5 mouse embryos. Oligodendrocytes were observed only in diencephalic cultures which contained DM-20+ cells, but not in mesencephalic or cortical cultures which did not. As these experiments

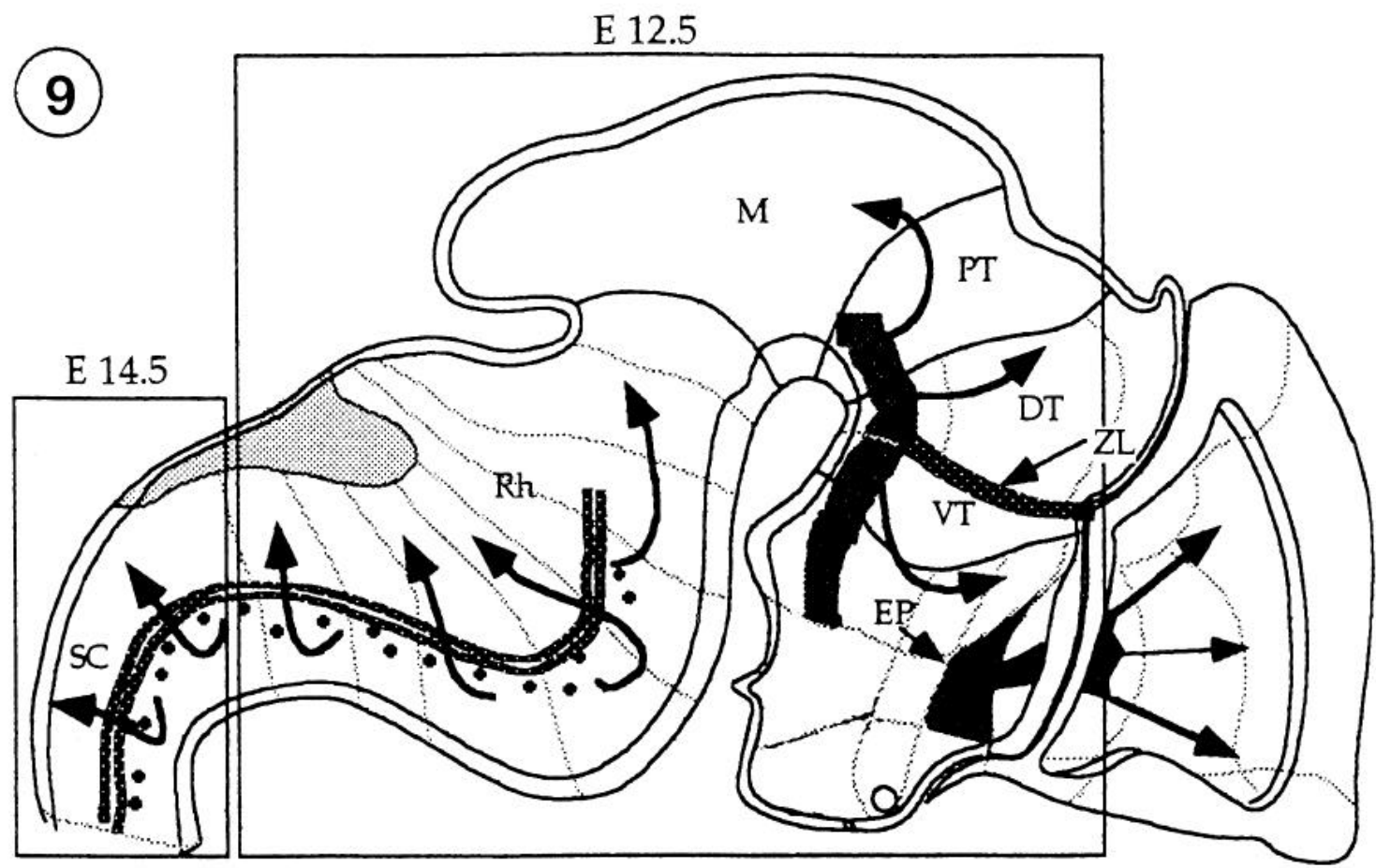

Figure 9. Schematic reconstruction showing the pattern of distribution and putative migration of DM-20-expressing oligodendrocyte precursors. The localization of DM-20 $0^{+}$cells in the brain and in the spinal cord is shown in squares $E 12.5$ and $E 14.5$, respectively. In the rhombencephalon, DM-20+ cells are disposed along two columns along the ventral portion of the central canal. In the prosencephalon, one group of DM-20 $0^{+}$cells is radially aligned along the zona limitans between the ventral and dorsal thalamus; a second group of DM-20+ cells located in the basal plate of the diencephalon and hypothalamus and in the entopeduncular area corresponds to the pool of putative oligodendrocyte precursors in the mid- and forebrain. Large arrows indicate the presumptive migration pathways of oligodendrocyte precursors. $E P$, entopeduncular area; $V T$, ventral thalamus; $D T$, dorsal thalamus; $P T$, pretectum; $Z L$, zona limitans intrathalamica, the P2/P3 interprosomeric boundary (IPB) zona limitans between the ventrothalamic $(V T=\mathrm{P} 3)$ and the dorsothalamic $(D T=\mathrm{P} 2)$ prosomers; $M$, mesencephalon; $R h$, rhombencephalon; $S C$, spinal cord. 
were performed in a chemically defined medium in the absence of any added growth factors such as PDGF or basic FGF, our data strongly suggest the existence, in the E12.5 diencephalon, of precursor cells with a restricted potentiality to differentiate into oligodendrocytes. Although oligodendrocytes developed in cultures of regions containing DM- $20^{+}$cells, we cannot affirm that it was these cells that gave rise to the oligodendrocytes.

There are arguments, indeed, against the possibility that the DM-20 $0^{+}$cells detected before E14.5 reflect early commitment to the oligodendrocyte lineage. First, the transition from early labeled cells in the neuroepithelium to isolated oligodendrocyte progenitors in the mantlc laycr and white matter was limited to the longitudinal zone of the basal plate, and fewer cells were produced than would be expected. Second, the above discussed restriction concerning neuronal markers applied even more at E12.5, since at E14.5 there are fewer postmitotic neurons. Expression of DM-20 in glial precursors that are generated and begin to migrate at E14.5 may therefore occur independently of earlier expression of the $P L P / D M-20$ gene in basal plate ventricular cells. Since the basal plate gives rise to diverse neuronal populations (Marchand et al., 1986; Puelles et al. 1987 ), the products of the $P L P / D M-20$ gene might play a transitory role in neurogenesis or in the histogenesis of the forebrain. The clear-cut transitory presence of DM-20 at one interneuromeric boundary at E12.5, the $\mathrm{P} 2 / \mathrm{P} 3$ interprosomeric boundary (intrathalamic zona limitans, Fig. 5C), suggests a role in positional specification, possibly in conjunction with other genes, such as Wnt-3A (Roelink and Nusse, 1991; Bulfone et al., 1993), that are also partially restricted to this locus that differentiates into a palisade of radial glia.

\section{Expression of DM-20 mRNA in Schwann cells and ensheathing cells}

In the present study DM-20 mRNA was detected in neural crest derivatives throughout the embryonic development of the mouse PNS. At E12.5, in addition to the ganglionic signal appearing at E9.5, DM- $20^{+}$cells were also observed in the limb bud and in the wall of the gut, suggesting that all three types of glial cells in the PNS-satellite glia, Schwann cells, and enteric glia-expressed the transcript, although we have not determined whether the signal corresponds to DM-20, PLP, or both.

DM-20-expressing cells observed in the peripheral olfactory system may be ensheathing cells, derived from the olfactory placodes, that enwrap the olfactory nerve. They may also include immature neurons, however, since prospective GnRH neurons originate in the vomeronasal organ and migrate to the preoptic area (Schwanzel-Fukuda et al., 1985; Wray et al., 1989). Although secondary neurons of the olfactory pathways were not labeled, it is interesting to note that DM- $20^{+}$cells were observed in projection sites of the olfactory system, that is, the lateral and accessory olfactory nuclei in the medial amygdala.

At present, the function of PLP/DM-20 in neural crest glial derivatives is unclear, inasmuch as PLP mutants do not display evident abnormalities in the PNS. It is well established that PLP/DM-20 is not a constituent of the PNS myelin, but several authors have reported that products of the PLP gene are expressed in the Schwann cells (Puckett et al., 1987; Pham-Dinh et al., 1991).

In conclusion, we propose DM-20 as a marker of the oli- godendrocyte lineage during embryonic development. The distribution of $\mathrm{DM}-20^{+}$cells suggests, as illustrated diagrammatically in Figure 9, that oligodendrocytes arise from two different pools of ventral precursors. One pool, localized in the hindbrain and spinal cord, is uniformly distributed along the central canal. As suggested by Warf et al. (1991), the commitment of these cells toward the oligodendrocyte lineage may result from cordal induction. The second pool of progenitors, localized in the caudal part of the diencephalon at E14.5, will give birth to the oligodendrocytes in the mid- and forebrain. Whether this second pool arises from an already committed subgroup of cells in the laterobasal plate of the diencephalon, expressing DM-20 at E9.5, remains to be established. The dramatic perturbation of the oligodendrocyte lineage in $P L P / D M$ 20 mutants, such as jimpy, strongly suggests that DM-20 plays a central role in differentiation along the oligodendroglial pathway.

\section{References}

Allinquant B, Staugaitis SM, D'Urso D, Colman DR (1991) The ectopic expression of myelin basic protein isoforms in Shiverer oligodendrocytes: implications for myelinogenesis. J Cell Biol 113: 393-403.

Altman J, Bayer SA (1984) The development of the rat spinal cord. Adv Anat Embryol Cell Biol 85:1-166.

Bally-Cuif L, Alvarado-Mallart R-M, Darnell DK, Wassef M (1992) Relationship between Wnt-1 and En-2 expression domains during early development of normal and ectopic met-mesencephalon. Development 115:999-1009.

Bulfone A, Puelles L, Porteus MH, Frohman MA, Martin GR, Rubenstein JLR (1993) Spatially restricted expression of Dlx-1, Dlx2(Tes-1), Gbx-2 and Wnt-3 in the embryonic day 12.5 mouse forebrain defines potential transverse and longitudinal boundaries. J Neurosci 13:3155-3172.

Choi BH, Kim RC (1985) Expression of glial fibrillary acidic protein by immature oligodendroglia and its implication. J Neuroimmunol 8:215-235.

Choi BH, Kim RC, Lapham LW (1983) Do radial glia give rise to both astroglial and oligodendroglial cells? Dev Brain Res 8:119 130

De Vitry F, Picart R, Jacques C, Legault L, Dupouey P, Tixier-Vidal A (1980) Presumptive colitition precursor for ncuronal and glial lineages in mouse hypothalamus. Proc Natl Acad Sci USA 77: 4165-4169.

Dubois-Dalcq M, Behar T, Hudson L, Lazzarini RA (1986) Emergence of three myelin proteins in oligodendrocytes cultured without neurons. J Cell Biol 102:384-392.

Easter SS Jr, Ross LS, Frankfurter A (1993) Initial tract formation in the mouse brain. J Neurosci 13:285-299.

Fontaine B, Changeux JP (1989) Localization of nicotinic acetylcholine receptor $\alpha$-subunit transcripts during myogenesis and motor endplate development in the chick. J Cell Biol 108:1025-1037.

Hart IK, Richardson WD, Heldin C.-H, Westermark B, Raff MC (1989) PDGF receptors on cells of the oligodendrocyte-type-2 astrocyte (O-2A) cell lineage. Development 109:595-603.

Hirano M, Goldman JE (1988) Gliogenesis in the rat spinal cord: evidence for origin of astrocytes and oligodendrocytes from radial precursors. J Neurosci 21:155-167.

Ikenaka K, Kagawa T, Mikushiba K (1992) Selective expression of DM-20, an alternatively spliced myelin proteolipid gene product, in developing nervous system of the mouse. J Neurochem 58:22482253.

Kitagawa K, Sinoway MP, Yang C, Gould RM, Colman DR (1993) A proteolipid protein gene family: expression in sharks and rays and possible evolution from an ancestral gene encoding a poreforming polypeptide. Neuron 11:433-448.

Knapp PE, Skoff RP (1987) A defect in the cell cycle of neuroglia in the myelin deficient jimpy mouse. Dev Brain Res 35:301-306.

Knapp PE, Skoff RP, Redstone DW (1986) Oligodendroglial cell death in jimpy mice: an explanation for the myelin deficit. $J$ Neu. rosci 6:2813-2822. 
Lafont F, Rouget M, Rousselet A, Valenza C, Prochiantz A (1993) Specific responses of axons and dendrites to cyloskeleton perturbations: an in vitro study. J Cell Sci 104:433-443.

Lees MB, Brostoff SW (1984) Proteins of myelin. In: Myelin (Morell P, ed), pp 197-224. New York: Plenum.

Levine SM, Goldman JE (1988) Spatial and temporal patterns of oligodendrocyte differentiation in rat cerebrum and cerebellum. J Comp Neurol 277:441-455.

Lubetzki C, Goujet-Zalc C, Gansmuller A, Monge M, Brillat A, Zalc B (1991) Morphological, biochemical and functional characterization of bulk isolated glial progenitor cells. J Neurochem 56:671680.

Lubetzki C, Demerens C, Anglade P, Villaroya H, Frankfurter A, Lee VM-Y, Zalc B (1993) Even in culture, oligodendrocytes myelinate solely axons. Proc Natl Acad Sci USA 90:6820-6824.

Marchand R, Lajoie L, Blanchet C (1986) Histogenesis at the level of the basal forebrain: the entopeduncular nucleus. Neuroscience 17:591-607.

McKinnon RD, Matsui T, Aaronson S, Dubois-Dalcq M (1989) FGF inhibits myelin gene expression and induces the PDGF A receptor in differentiating O-2A glial progenitor cells. J Cell Biol 109:97102.

Miller RH, Szigeti V (1991) Clonal analysis of astrocyte diversity in neonatal rat spinal cord cultures. Development 113:353-362.

Monge M, Kadiisky D, Jacques C, Zalc B (1986) Oligodendroglial expression and deposition of four major myelin constituents in the myelin sheath during development. Dev Neurosci 8:222-235.

Moody SA, Quigg MS, Frankfurter A (1987) Development of the peripheral trigeminal system in the chick revealed by an isotypespecific anti-beta-tubulin monoclonal antibody. J Comp Neurol 279: $567-580$.

Noll E, Miller RH (1993) Oligodendrocyte precursors originate at the ventral ventricular zone dorsal to the ventral midline region in the embryonic rat spinal cord. Development 118:563-573.

Nornes HO, Das GD (1974) Temporal pattern of neurogenesis in spinal cord of rat. I. An autoradiographic study. Time and sites of origin and migration and settling patterns of neuroblasts. Brain Res 73:121-138.

Pham-Dinh D, Birling MC, Roussel G, Dautigny A, Nussbaum JL (1991) Proteolipid DM-20 predominates over PLP in PNS. Neuroreport 2:89-92.

Pringle NP, Richardson WD (1993) A singularity of PDGF alphareceptor expression in the dorsoventral axis of the neural tube may define the origin of the oligodendrocyte lineage. Development 117: 525-533.

Pringle NP, Mudhar HS, Collarini EJ, Richardson WD (1992) PDGF receptors in the rat CNS: during late neurogenesis, PDGF alphareceptor expression appears to be restricted to glial cells of the oligodendrocyte lineage. Development 115:535-551.

Privat A, Leblond CP (1972) The subependymal layer and neighbouring region in the brain of young rats. J Comp Neurol 142:277302 .
Privat A, Valat J, Lachapelle F, Baumann N, Fulcrand J (1982) Radivautographic evidence for the protracted proliferation of glial cells in the brain of jimpy mice. Dev Brain Res 2:411-416.

Puckett C, Hudson L, Ono K, Friedrich V, Benecke J, Dubois-Dalcq M, Lazzarini RA (1987) Myelin specific proteolipid protein is expressed in myelinating Schwann cells but not incorporated into myelin sheath. J Neurosci Res 18:511-518.

Puelles L, Rubenstein JLR (1993) Expression patterns of homeobox and other putative regulatory genes in the embryonic mouse forebrain suggest a neuromeric organization. Trends Neurosci 16:472479.

Puelles L, Amat JA, Martinez-de-la-Torre M (1987) Segment-related, mosaic neurogenetic pattern in the forebrain and mesencephalon of early chick embryo: I. Topography of AchE-positive neuroblasts up to stage HH18. J Comp Neurol 266:247-268.

Ranscht B, Clapshaw PA, Price J, Noble M, Seifert W (1982) Development of oligodendrocytes and Schwann cell studied with a monoclonal antibody against galactocerebroside. Proc Natl Acad Sci USA 79:2709-2713.

Richardson WD, Pringle N, Mosley MJ, Westermark B, Dubois-Dalcq M (1988) A role for platelet derived growth factor in normal gliogenesis in the central nervous system. Cell 53:309-319.

Roelink H, Nusse R (1991) Expression of two members of the Wnt family during mouse development-restricted temporal and spatial patterns in the developing neural tube. Genes Dev 5:381-388.

Schneider A, Montague P, Griffiths I, Fanarraga M, Kennedy P, Brophy P, Nave K-A (1992) Uncoupling of hypomyelination and glial cell death by a mutation in the proteolipid protein gene. Nature 358 : 758-761.

Schwanzel-Fukuda M, Morrell JI, Pfaff DW (1985) Ontogenesis of neurons producing luteinizing hormone releasing hormone (LHRH) in the nervus terminalis of the rat. J Comp Neurol 238:348-364.

Skoff RP (1976) Myelin deficit in the jimpy mouse may be due to cellular abnormalities in astroglia. Nature 264:560-562.

Timsit SG, Bally-Cuif L, Colman DR, Zalc B (1992) DM-20 mRNA is expressed during early embryonic development of the nervous system of the mouse. J Neurochem 58:1172-1175.

Trapp BD, Moench T, Pulley M, Barbosa E, Tennekoon G, Griffin J (1987) Spatial segregation of mRNA encoding myelin-specific proteins. Proc Natl Acad Sci USA 84:7773-7777.

Warf BC, Fok-Seang J, Miller RH (1991) Evidence for the ventral origin of oligodendrocyte precursors in the rat spinal cord. J Neurosci 11:2477-2488.

Williams BP, Read J, Price J (1991) The generation of ncurons and oligodendrocytes from a common precursor cell. Neuron 7:685693.

Wray S, Nieburgs A, Elkabes S (1989) Spatiotemporal cell expression of luteinizing hormone-releasing hormone in the prenatal mouse: evidence for an embryonic origin in the olfactory placode. Dev Brain Res 46:309-318.

Yan Y, Lagenaur C, Narayan-V (1993) Molecular cloning of M6: identification of a PLP/DM-20 gene family. Neuron 11:423-431. 